\title{
Perancangan Sistem Informasi Perkembangan Akademik Online Taman Kanak-Kanak Pada Smartphone Berbasis Android
}

\author{
Joash Lorenzo Imbenay dan Yulianus Palopak \\ Fakultas Teknologi Informasi, Universitas Advent Indonesia
}

\begin{abstract}
Abstrak
Penggunaan smartphone sebagai device akses informasi berkembang sangat pesat. Terlebih lagi, banyak aplikasi mobile yang diciptakan membuat informasi-informasi yang dibutuhkan mudah untuk didapat. Tidak hanya sebagai device untuk komunikasi saja, namun telah beralih fungsi menjadi perangkat yang memudahkan pekerjaan manusia. Smartphone dengan sistem operasi Android memiliki kelebihan dengan akses internet yang cepat namun dengan harga yang relatif murah jika dibandingkan dengan smartphone lainnya. Keunggulan tersebut membuat berbagai pihak berlomba-lomba mengembangkan aplikasi pada sistem operasi Android, tidak terkecuali dengan Sistem Informasi Nilai Online pada taman-kanak. Penulis memanfaatkan teknologi Android untuk merancang Sistem Informasi Nilai Online pada smartphone berbasis Android. Dengan aplikasi ini, pengguna tidak perlu lagi membuka Sistem Informasi Nilai Online Taman Kanak-kanak pada browser dengan dukungan perangkat komputer, tetapi hanya dengan menggunakan smartphone berbasis Android. Adapun tujuan penelitian ini yaitu untuk memudahkan penyampaian informasi nilai hasil belajar siswa dari pihak sekolah kepada orangtua atau wali siswa. Metodologi yang digunakan dalam penelitian ini adalah metode Waterfall, dimana penulis menganalisa kebutuhan, desain sistem, membuat sistem, menguji sistem, dan menerapkan sistem. Aplikasi ini dibangun menggunakan Android Studio sebagai IDE (Integrated Development Environment). Adapun untuk berkomunikasi dengan server database, aplikasi menggunakan JSON Parse sebagai jembatan untuk bertukar data dengan server database. Secara garis besar, aplikasi telah mampu berjalan dengan baik seperti mengakses data siswa, data guru, rapor dan laporan harian serta mengganti password dari pengguna. Namun, masih dibutuhkan pengembangan di bagian antarmuka pengguna dan pengembangan pada berbagai platform selain Android.

Kata-kata kunci: Sistem Informasi, Nilai Online, Android, mobile, Taman Kanak-kanak
\end{abstract}

\section{Online Information System Design For The Akademic Progress Of Kindergarten Based On Android Smartphone}

\begin{abstract}
The use of a smartphone as a device access to information was growing very rapidly. Moreover, many mobile applications were created to make the required information easily accessible. Not only as a device for communication, but had been converted to a device that facilitates the work of human kind. Smartphones with Android operating system had advantages with fast internet access but the price is relatively cheap when compared to other smartphones. These advantages make the various parties competing to develop applications on the Android operating system, was no exception with the Online Information System for The Grades of Kindergarten. Authors used Android technology for designing Grades Information System Online on Android-based smartphone. With this application, users no longer need to open System Information Online Grades kindergarten in the browser with the support of computers, but only by using a smartphone based on Android. The purpose of this study is to easily provide information on the results of learning outcomes of students from the school to parents or guardians of students. The methodology used in this research is Waterfall method, where author analyzes requirements, design the system, making the system, test the system, and implementing the system. This application is built using Android Studio as an IDE (Integrated Development Environment). For communicating with the database server, this application used the JSON Parse as a bridge to exchange data with the database server. Broadly speaking, the application had been able to go well as access to student data, teacher data, daily reports, report cards and change the password of the user. However, this application still needs to be developed in parts of the user interface and development on various platforms other than Android.
\end{abstract}




\section{Pendahuluan}

Perkembangan teknologi yang diciptakan oleh manusia khususnya dalam bidang teknologi telekomunikasi yang semakin maju membuat informasi dapat disampaikan dengan cepat. Salah satu perkembangan teknologi telekomunikasi adalah adanya smartphone. Dengan adanya smartphone, manusia dapat melakukan komunikasi tanpa kabel (wireless) sehingga memungkinkan untuk dibawa ke mana saja dengan syarat masih terjangakau oleh sinyal dari jaringan operator yang digunakan.

Seiring dengan perkembangan zaman, teknologi informasi khususnya sistem operasi Android telah berkembang dengan sangat pesat dan telah melekat dengan kehidupan masyarakat. Saat ini, smartphone yang bersistem operasi Android tidak hanya digunakan oleh kalangan menengah atas saja tetapi juga banyak digunakan oleh kalangan menengah bawah. Tidak hanya orang dewasa, anak-anak pun sudah sangat mahir dalam menggunakannya (Hakkun dkk, 2012:1).

Android merupakan salah satu sistem operasi pada smartphone yang sangat digemari saat ini dimana dari segi pertumbuhan penggunaannya di Indonesia, dari tahun ketahun Android termasuk unggul. Yang penggunanya mencapai lebih dari 2,5 juta orang ditahun 2013 menurut World Quarterly Mobile Phone Tracker (Rizqi, 2013). Selain unggul karena bersifat open source, sistem operasi Android juga terkenal dengan fitur realtime multitasking. Sistem operasi ini memungkinkan penggunanya untuk menjalankan beberapa aplikasi sekaligus secara bersamaan. Para pengembang Android pun mulai mengembangkan berbagai macam aplikasi dalam berbagai bidang, tidak terkecuali juga aplikasi pengolahan data di bidang pendidikan.

Pada umumnya, pengolahan data siswa di sekolah-sekolah masih dilakukan dengan cara manual. Yaitu setiap wali kelas mengisi rapor siswa dengan cara tulis tangan, karena sistem ini belum bisa melakukan pengolahan data secara keseluruhan. Sering kali guru mengeluhkan cara penulisan rapor yang masih manual karena terdapat banyak kesulitan seperti coretan dan bahkan kesalahan dalam pengisian rapor sedangkan dalam penulisan rapor Taman Kanak-kanak ini dituntut harus lebih rapih, bersih dan dapat dibaca dengan jelas oleh orangtua anak.

Kesibukan akan pekerjaan juga menjadi penyebab kurang efektifnya pembagian rapor secara manual atau dengan undangan kepada orangtua untuk menghadiri penerimaan rapor di sekolah. Orangtua akan sulit membagi waktu untuk datang dan mengambil rapor anak ke sekolah.

\section{Landasan Teori \\ Konsep Dasar Sistem Informasi}

Sistem informasi adalah satu sistem berbasis komputer yang menyediakan informasi bagi beberapa pengguna dengan kebutuhan yang serupa. Para pengguna biasanya tergabung dalam suatu entitas organisasi formal, seperti departemen atau lembaga suatu instansi pemerintahan yang dapat dijabarkan menjadi direktorat, bidang, bagian sampai pada unit terkecil di bawahnya (Jogiyanto, 2005:11).

\section{Aplikasi Bergerak}

Kata mobile mempunyai arti bergerak atau berpindah. Sehingga diperoleh pengertian bahwa aplikasi bergerak merupakan aplikasi yang dapat dijalankan walaupun pengguna berpindah atau karena pengguna berpindah. Pemrograman aplikasi bergerak tidak banyak berbeda dengan pemrograman konvensional pada PC. Aspek karakteristik dari perangkat bergerak sering mempengaruhi arsitektur dan implementasi dari aplikasi tersebut. Dalam pemrograman aplikasi bergerak berbagai aspek teknis perangkat lebih menonjol karena memiliki banyak keterbatasan dibandingkan komputer konvensional atau PC. (Daryatmo dkk, 2007:1).

\section{Java}

Menurut Sun Microsystem, Java adalah nama untuk sekumpulan teknologi untuk membuat dan menjalankan perangkat lunak pada komputer standalone ataupun pada lingkungan jaringan. Java berdiri di atas sebuat mesin intrepreter yang diberi nama Java Virtual Machine (JVM). Bahasa Java disebut sebagai bahasa yang portable karena dapat dijalankan pada berbagai sistem operasi, asalkan pada sistem operasi tersebut terdapat JVM (Shalahuddin, 2008:1)

\section{Android}

Android adalah sistem operasi untuk telepon seluler berbasis Linux sebagai kernelnya. Perkembangan Android yang begitu pesat perkembangan di era ini adalah karena Android menyediakan platform terbuka (Open Source) bagi para pengembang untuk menciptakan aplikasi mereka sendiri. 
Awalnya, perusahaan search engine terbesar saat ini, yaitu Google Inc. membeli Android Inc., pendatang baru yang membuat peranti lunak untuk ponsel. Android, Inc. didirikan oleh Andy Rubin, Rich Milner, Nick Sears, dan Chris White pada tahun 2003. Pada Agustus 2005 Google membeli Android Inc. Kemudian untuk mengembangkan Android dibentuklah Open Handset Alliance konsorsium dari 34 perusahaan hardware, software, dan telekomunikasi, termasuk Google, HTC, Intel, Motorola, Qualqomm, T-Mobile dan Nvidia (Pratama 2011:1).

\section{Structured Query Language (SQL)}

SQL merupakan bahasa query standar yang digunakan untuk mengakses database. Fungsi paling dasar dari SQL adalah untuk menampilkan data dari database. Selanjutnya, kita dapat melakukan filter dan memanipulasi data sesuai dengan kebutuhan. Perintah- perintah dalam SQL terbagi dalam dua kelompok besar yaitu DDL dam DML (Jatnika, 2010:1).

\section{Data Definition Language (DDL)}

DDL digunakan untuk mendefinisikan, mengubah, serta menghapus basis data dan objek-objek yang diperlukan dalam basis data. Secara umum, DDL yang digunakan adalah CREATE untuk membuat objek baru, USE untuk menggunakan objek, ALTER untuk mengubah objek yang sudah ada, dan DROP untuk menghapus objek. DDL biasanya digunakan oleh administrator basis data dalam pembuatan sebuah aplikasi basis data (Fathansyah, 2007).

2. Data Manipulation Language (DML)

Selain untuk mengambil informasi dari basis data, SQL juga dapat digunakan untuk memanipulasi data. Proses tersebut meliputi mengambil, menambah, menghapus, dan mengedit data. Perintah manipulasi data sangat sering digunakan dalam aplikasi basis data dan bahkan dapat dikatakan menjadi inti sebuah aplikasi. Sebuah tabel dapat diisi dengan data, dihapus, maupun diedit

\section{Unified Modeling Language (UML)}

UML adalah sekumpulan pemodelan konvensi yang digunakan untuk menentukan atau menggambarkan sebuah sistem perangkat lunak yang berhubungan dengan objek. UML Diagram dapat diibaratkan seperti sebuah cetak biru untuk membangun sebuah rumah. Sebuah cetak biru umumnya membantu pembangunan dengan gambaran yang jelas untuk saluran air, listrik, pemanas, dan sejenisnya. Setiap UML Diagram membantu tim developer program dengan gambaran yang jelas untuk sistem tersebut (Whitten dkk, 2004:430). Beberapa contoh diagram UML diantaranya adalah:

\section{Use Case Diagram}

Diagram ini dipakai untuk menggambarkan himpunan use case dan aktor-aktor, dengan kasus yang disesuaikan dengan langkah-langkah yang telah ditentukan. Use Case Diagram merupakan metode yang cocok digunakan untuk dapat menggambarkan interaksi yang jelas antara sistem dengan pengguna (Dharwiyanti, 2003:4).

2. Class Diagram

Diagram ini digunakan untuk menggambarkan struktur objek statis dalam sebuah sistem, dan menunjukkan sistem tersusun dari kelas-kelas apa saja dan hubungan apa saja yang terbentuk di antara kelas tersebut (Dharwiyanti, 2003:5).

3. Sequence Diagram

Diagram ini dipakai untuk menggambarkan interaksi yang menekankan pada pengiriman pesan (message) dalam suatu waktu tertentu. Diagram ini mengilustrasikan bagaimana pesan dikirim dan diterima antara objek dan urutan yang seperti apa. Diagram ini lebih detail dalam penggambaran aliran data, termasuk data yang dikirim ataupun diterima (Dharwiyanti, 2003:8).

4. State Chart Diagram

Diagram ini dipakai untuk menggambarkan state-state pada sistem, memuat state, transisi, event, dan aktivitas. Diagram ini membantu menjelaskan sifat dinamis dan antarmuka, kelas, kolaborasi, dan pemodelan sistem-sistem yang reaktif (Dharwiyanti, 2003:7).

5. Activity Diagram

Diagram ini dipakai untuk menggambarkan alur yang berurutan dari suatu aktivitas ke aktivitas lainnya dalam suatu sistem. Activity Diagram juga bisa dipakai untuk memodelkan berbagai aksi yang dilakukan saat sebuah operasi dieksekusi, dan memodelkan hasil dari aksi tersebut. Dari diagram ini, kita dapat melihat bagaimana aktivitas dalam suatu sistem, dari mulai hingga saat sistem berakhir. Setiap use case memiliki setidaknya satu diagram aktivitas (Dharwiyanti, 
2003:7).

\section{Hypertext Preprocessor (PHP)}

Menurut Abdul Kadir (2008:2), PHP dibuat pertama kali oleh Rasmus Lerdorf pada tahun 1995. PHP adalah sekumpulan script yang digunakan untuk mengolah data form dari web yang kemudian ditempatkan ke dalam server dan diproses kembali pada server. Hasilnya akan dikirimkan ke klien, tempat pemakai menggunakan browser.

PHP saat ini cukup populer sebagai perangkat pemrograman $w e b$, terutama di ruang lingkup Linux, dan PHP juga bekerja dengan web server. Pada aplikasi ini, PHP akan digunakan untuk kepentingan sistem basis data, sebagai platform untuk maintenance sistem basis data.

\section{Javascript Object Notation Parse}

Menurut situs web resmi JSON, JSON (Javascript Object Notation) merupakan format yang digunakan dalam pemrograman web untuk transfer data, Agar setiap platform yang berbeda dapat saling berkomunikasi. Contoh, android dengan MySQL ingin berkomunikasi dibutuhkan suatu service yang disebut dengan JSON.

\section{Pengertian Rapor}

Menurut Kamus Besar Bahasa Indonesia (KBBI), kata rapor didefinisikan sebagai laporan resmi kepada yang wajib menerimanya. Buku rapor adalah suatu cara pengukuran kinerja siswa. Umumnya laporan ini diberikan oleh sekolah kepada siswa atau orangtua siswa dua kali hingga empat kali dalam setahun. Rapor merupakan dokumen yang menjadi penghubung komunikasi baik antara sekolah dengan orangtua peserta didik maupun dengan pihak-pihak lain yang ingin mengetahui tentang hasil belajar anak pada kurun waktu tertentu. Karena itu, rapor harus komunikatif, informatif, dan komprehensif dalam memberikan gambaran tentang hasil belajar peserta didik.

\section{Analisis dan Perancangan Sistem Analisis Sistem Lama}

Berdasarkan analisis identifikasi kebutuhan yang ada, mengapa perlu dibangun suatu sistem laporan hasil belajar karena masih terbatasnya sistem informasi yang ada di sekolah. Salah satunya adalah tentang laporan hasil belajar yang masih bersifat manual. Laporan hasil belajar hanya dibagikan melalui rapor kepada orangtua pada hari penerimaan rapor saja, sehingga orangtua yang tidak sempat mengambil rapor anaknya tidak bisa mengetahui laporan hasil belajar dari anaknya di sekolah.

\section{Analisis Kebutuhan Sistem Baru}

Dari analisis kebutuhan lama yang ada, dibutuhkan adanya suatu sistem yang baru untuk membantu guru dan orangtua sehingga lebih efisien dalam penyampaian laporan hasil belajar. Sesuai dengan topik penulis untuk membangun sebuah mobile application untuk smartphone berbasis Android. Secara umum dapat dijelaskan tentang aplikasi ini dengan menggunakan smartphone yang sudah diinstalasi aplikasi ini, aplikasi akan mengambil data dari database dan aplikasi akan menampilkan data yang diperlukan oleh pengguna.

\section{Perancangan Sistem}

Berdasarkan analisis identifikasi masalah yang ada, maka diperlukan persiapan yang baik untuk memcahkan suatu masalah. Tahap perancangan dalam pembuatan yaitu sebagai berikut:

1. Analisis Kebutuhan

2. Arsitektur Sistem Lama

3. Arsitektur Sistem Baru

4. Use Case Diagram

5. Activity Diagram

6. Sequence Diagram

7. Tabel dan Kamus Data

8. Class Diagram

9. Deployment Diagram 


\section{Hasil dan Perancangan \\ Halaman Log In}

Halaman ini muncul setiap kali aplikasi SINO-TK dibuka sewaktu user belum Log In. Untuk mengakses fitur SINO-TK, user harus Log In dengan cara mengsi NIS dan password yang sudah terdaftar pada basis data SINO-TK.

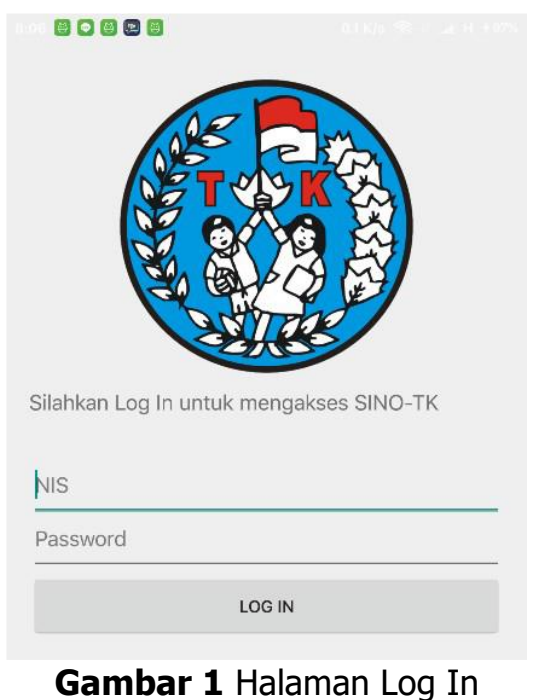

\section{Halaman Home}

Halaman Home dapat diakses setelah user berhasil melakukan Log In ke dalam sistem. Halaman ini merupakan halaman utama dari aplikasi SINO-TK. Halaman ini menampilkan pesan selamat datang dan juga menampilkan nama dari useryang sedang Log in. Termasuk juga cara menggunakan aplikasi ini.

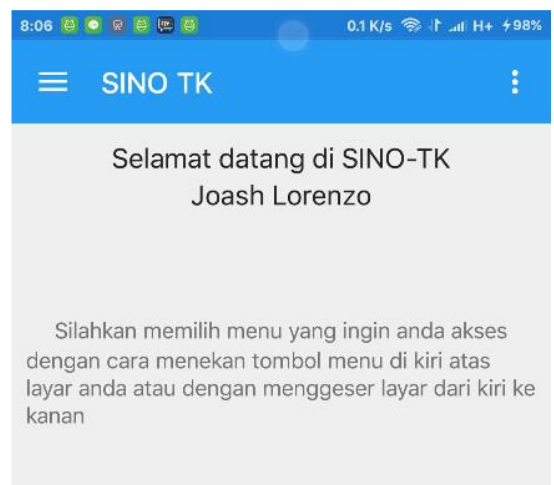

Gambar 2 Halaman Home

\section{Navigation View}

Navigation View merupakan menu yang berada pada samping kanan layar dan bisa di tampilkan dengan cara menekan tombol menu pada kiri atas layar atau dengan menggeser layar dari kiri ke kanan. Pada Navigation view terdapat menu-menu diantaranya yaitu menu untuk menampilkan profil siswa, melihat halaman Home, data guru-guru, mengakses rapor, mengakses laporan harian, melihat info sekolah, mengganti password dan log out yang dapat di akses oleh user yang sudah berhasil melakukan Log In. 


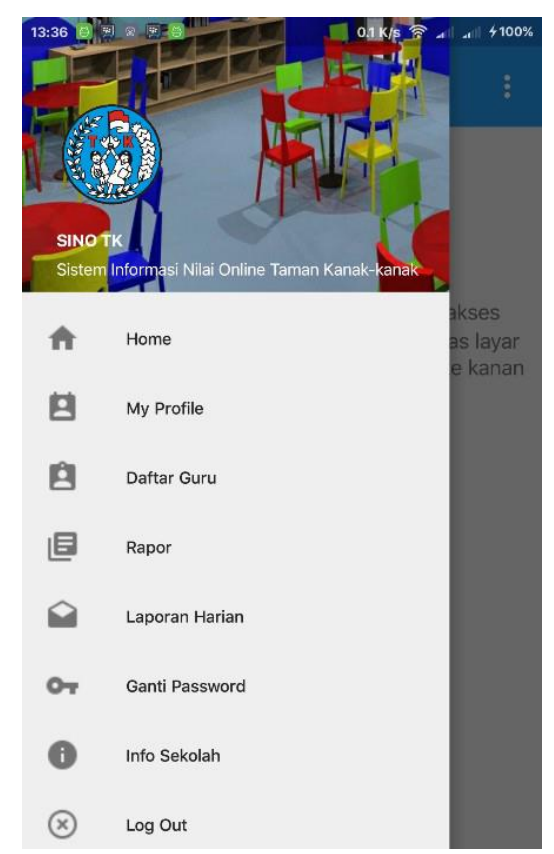

Gambar 3 Navigation View

\section{Halaman My Profile}

Halaman ini menampilkan detil data dari useryang sedang Log In. Mulai dari nama, NIS sampai dengan foto dan kontak yang dapat dilihat.

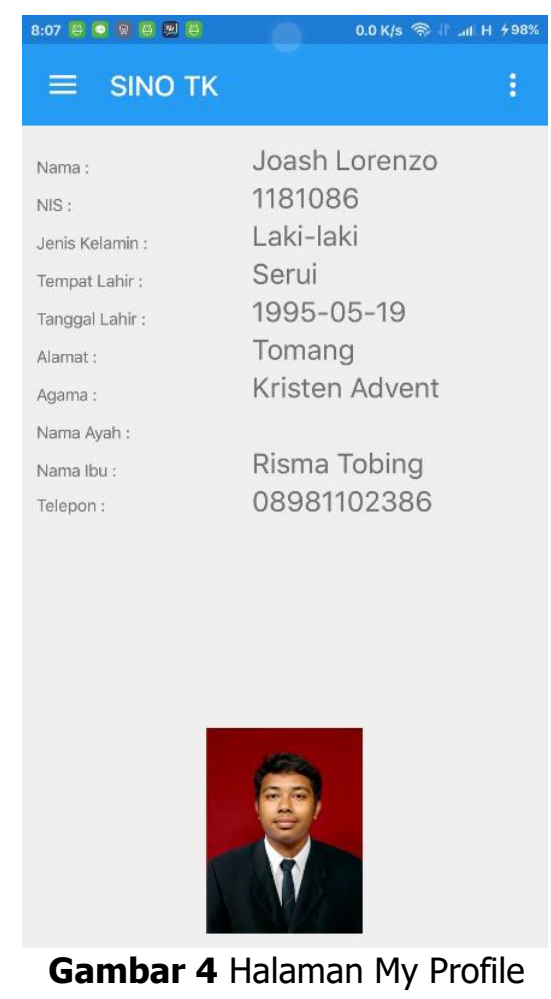

\section{Halaman Daftar Guru}

Halaman ini menampilkan daftar dari guru-guru yang ada pada sistem. Ketika salah satu data diklik maka detil dari data guru tersebut akan di tampilkan. Fungsi telepon dan sms langsung menggunakan aplikasi sms dan telepon default smartphone juga dapat di akses melalui halaman ini. 


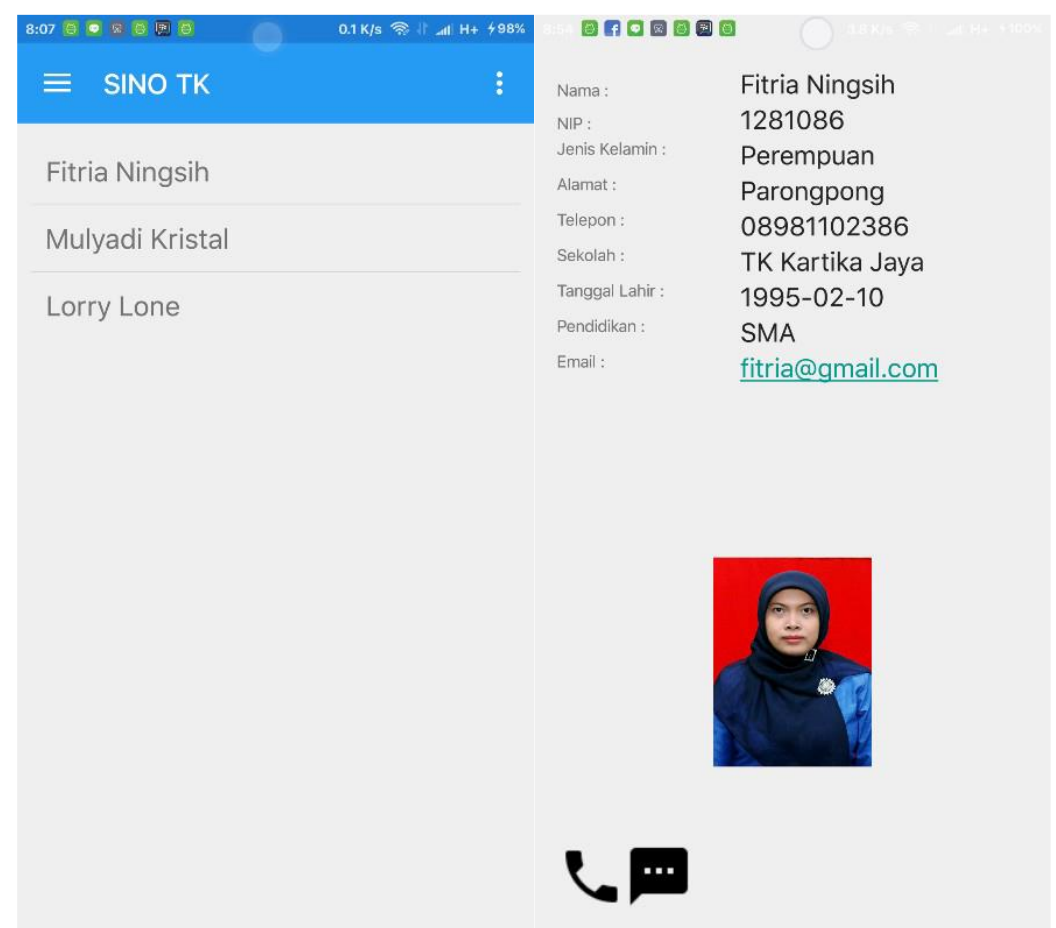

Gambar 5 Daftar Guru

\section{Halaman Rapor}

Halaman Rapor menampilkan rapor yang sudah di input ke dalam basis data SINO TK sesuai dengan user yang melakukan Log In. Terdapat hasil dari pembelajaran dan perkembangan siswa di sekolah.

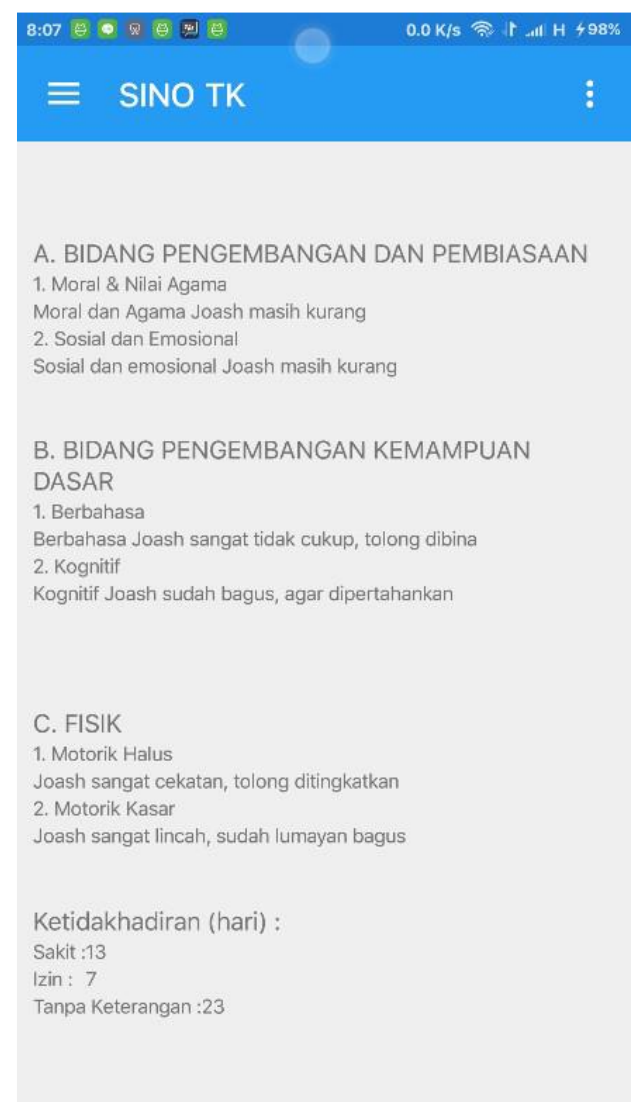

Gambar 6 Halaman Rapor 


\section{Halaman Laporan Harian}

Pada halaman ini, aplikasi akan menampilkan semua catatan harian guru untuk user yang sedang Log In. Catatan atau laporan harian ini berupa list atau daftar.

\begin{tabular}{l}
\hline S:07 \\
$\equiv$ SINO TK \\
2016-05-25 \\
hari ini Joash berkelahi dengan teman \\
sebangkunya \\
2016-05-26 \\
Joash sudah bisa membaca dengan \\
lancar \\
2016-05-27 \\
Joash tidak menghabiskan bekal \\
makanannya \\
2016-05-28 \\
Joash sudah lancar berdoa Bapa kami \\
2016-05-29 \\
Joash sudah bisa menghitung dari 1 \\
sampai 10 menggunakan bahasa \\
inggris
\end{tabular}

Gambar 7 Halaman Laporan Harian

\section{Halaman Ganti Password}

Pada halaman ini, user dapat mengganti password dengan cara menginputkan password yang baru dua kali pada dua textbox dengan benar dan sama dan menekan tombol simpan password.

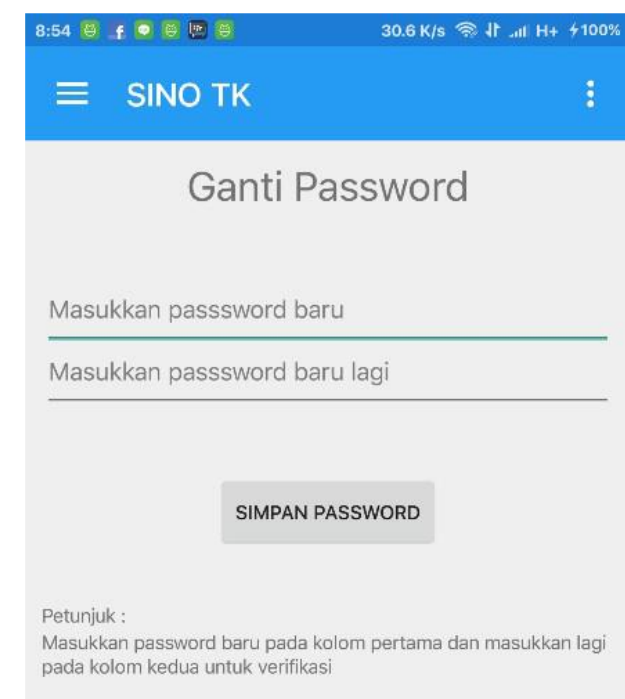

Gambar 8 Halaman Ganti Password

\section{Halaman Info Sekolah}

Pada halaman ini sistem akan menampilkan info dari sekolah user. Detil sekolah akan ditampilkan kepada user. 


\section{Kesimpulan dan Saran \\ Kesimpulan}

Dari hasil perancangan, pembangunan dan pembuatan Sistem Informasi Perkembangan Akademik Online Taman Kanak-kanak pada smartphone berbasis Android ini, penulis menyimpulkan bahwa:

1. Sistem Informasi Perkembangan Akademik Online Taman Kanak- kanak berbasis Android dapat memudahkan penyampaian perkembangan anak kepada orangtua.

2. Sistem rapor yang sebelumnya menggunakan media kertas atau manual dapat digantikan sepenuhnya dengan media digita/ yaitu dengan menggunakan smartphone berbasis Android.

\section{Saran}

Saran-saran yang dapat diperoleh dari perancangan, pembangunan dan pembuatan Sistem Informasi Perkembangan Akademik Online Taman Kanak-kanak pada smartphone berbasis Android ini diantaranya sebagai berikut:

1. Menambah Platform lain seperti Windows Phone dan iOS untuk pengembangan selanjutnya.

2. Memperkaya desain yang bagus dan menarik. Menambahkan berbagai fitur yang dapat membantu dalam proses pengelolaan laporan seperti menambahkan fitur notifikasi ketika rapor atau laporan harian telah diinput.

3. Menambahkan fungsi untuk guru dan admin yang dapat mengolah data melalui aplikasi Android, tidak hanya melalu web.

4. Menambahkan fitur untuk guru dan orangtua supaya bisa berinteraksi secara langsung melalui sistem ini sendiri

\section{Referensi}

1. Daryatmo, B. (2007). Diktat Inovasi Aplikasi Bergerak. Palembang.

2. Dharwiyanti, Sri. (2003). Pengantar Unified Modeling Language (UML). [Online]. Tersedia: http://ilmukomputer.com/. [8 Desember 2015].

3. Fathansyah. (2007). Basis Data. Bandung: Informatika.

4. Fitria, A. (2013). Studi Kasus Perkembangan Emosional Anak yang Mengikuti Paud dan Anak yang tidak mengikuti Paud di TK Permata Bunda. Jurnal Fakultas IImu Pendidikan UM.

5. Hakkun, Asmara dan Arisanti. (2012). Aplikasi Pembelajaran Bahasa Jerman Level Dasar Berbasis Android. Jurnal Politeknik Elektronika Negeri Surabaya Institut Teknologi Sepuluh Nopember.

6. Hendra, Jatnika. (2010). Basis Data Lanjutan. Bandung.

7. Jogiyanto, H. M. (2005). Sistem Teknologi Informasi. Edisi Kedua. Yogyakarta.

8. Jogiyanto, H. M. (2009). Analisis dan Desain Sistem Informasi. Yogyakarta: Andi Offset.

9. Kadir, Abdul (2008). Dasar pemrograman Web Dinamis Menggunakan PHP (Revisi). Yogyakarta: Andi Offset.

10. Shalahuddin, M. (2008). Pemograman J2ME Belajar Cepat Pemograman Perangkat Telekomunikasi Mobile. Bandung: Informatika.

11. Kathy, S. (2005). Head First Java. USA: O'Reilly.

12. Pratama, Widianto. (2011). Tutorial Android Programming. [Online]. Tersedia: http://greenbel.wordpress.com/. [8 Desember 2015].

13. Rizqi, R. F. (2014). Pembuatan Aplikasi Lembar Kerja Siswa Elektronik (ELks) Berbasis Android. Jurnal Fakultas Teknik Universitas Muhammadiyah Surakarta.

14. Whitten. (2004). System Analysis and Design Methods. The McGraw-Hill Companies, Inc. 